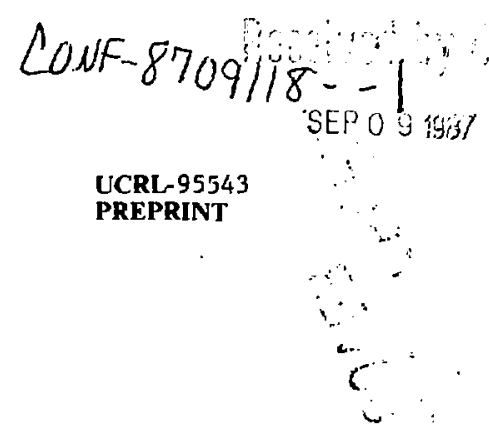

SPECIAL TARGETS FOR NUCLEAR REACTION AND SPECTROSCOYIC STUDIES

ROBERT G. LANIER

THIS PAPER WAS PREPARED FOR SUBHITTAL TO ACS SYMPOSIUY SERIES 324

DIVISION OF NUCLEAR CHEMISTRY AND TECHNOLOGY

CHICAGO, IL

SEPTEMBER 8-13, 1985

JULY 31,1987

This is a preprint of a paper intended for publication in a journal or proceedings. Since changes may be made before publication, this preprint is made available with the understanding that it will not be cited or reproduced without the permission of the author. 


\title{
Special Targets for Nuclear Reaction and Spectroscopic Studies
}

\author{
Robert G. Lanier \\ Nuclear Chemistry Division, Lawrence Livermore National Laboratory, Livermore, CA 94550
}

\begin{abstract}
Strongly focused and monoenergetic charged-particle beans from modern accelerators and targets fabricated from quantitiea of lootopically enriched and stable materials are the essential components from many current muclear physics experiments. Although a large body of this $\mathrm{kind}$ of experimental work requires substantial amounts of target material, an important subset of such experimenta can be done with as itttle as a few $\mu \mathrm{g}$ of material. Experiment. where charged particles or electrons cen be focused on or transported to a detector are examples of accelerator-based studles which can be ade with targete that contain relatively sall anounts of material. For these kinds of studies, it then becones possible to extend the domaln of potential target aterials to species which are very rare or which are unstable and undergo radloactive decay. At our laboratory during the last ten years, we have gide

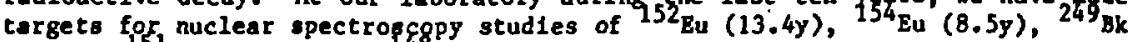
$(320 d),{ }^{15} \mathrm{Sa}(90 \mathrm{y})$, and $148 \mathrm{Gd}(75 \mathrm{y})$. We will report our experience with fabricating these and other kinds of stable targets and discuss our plans for preparing additional targets which offer lateresting and exciting prospects for future nuclear research studies.
\end{abstract}

Although there are always a varlety of technical difficulties associated with dolng any $k 1$ nd of nuclear sclence research, the problew of obtaining a reasonable target for various accelerator or reactor based experiaents is the nost pervasive, In priaciple, the 1dea of bringing together focused particle beans and stationary target nuclel is easily conceptualized. In practice, however, once an interesting physics study is 1dentified, the preparation of a sultable target usually involves signiflcant technical challenge and ingenulty. In this report, we describe some of our experience in our Nuclear Properties Group at the Lawrence LIvermore National Laboratory (LLNL) wth preparing speclal targets for nuclear research studies.

Our studies have Involved the use of both neutron and charged-particle beams and Table I presents a partial list of the targets prepared. The Nobel gas targets were prepared for in-beaw $\gamma$-ray studies which used an external thermal neutron beam. Large amounts of target matertal were required for these experiments and a special device - a cryostat - was constructed to 1solate and contain a large quantity of gas (1n the solid state) so that the measurements could be done. The details of the construction of this device, as well a $1,2,3$ various studies performed with it have been described

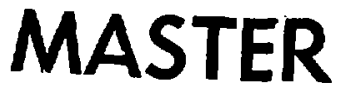


The $176_{\text {iu }}$ target is unlque becauge this material has an extremely low natural 1sotople sundance (2.612). A sample of several tens of milligrams of $\mathrm{Lu}_{2} \mathrm{O}_{3}$ was obtained from fhe Oak Ridge Natlonal Laboratory and had an 1sotopic enrlchnent of a $70 \mathrm{z}$ in $17 \mathrm{Lu}$. An additional 1sotope separation step was done on th1s saaple at HWL. By chis procedure we were able to make a target of 16otopically pure ${ }^{1 / 6}$ Le $(\sim 99.97)$ that had a thlckness of $\sim 22 \mathrm{mg} / \mathrm{cm}^{2}$ and Hbich was supported on a Th substrate. Th1s target was subsequently used for 160 Coulomb-excitation experiments.

The remainder of the $118 \mathrm{t}$ in Table I involves radioactive cargets which were prepared for charged-particle spectroscopy experiments. These targets were generally thin $\left(10-40 \mathrm{Hg} / \mathrm{cm}^{2}\right)$ and were used for scudies where $11 \mathrm{ght}-1$ on reaction products were measured with a magnetic spectrograph. In general, the procedure for preparing such targets involves three steps: (1) production of the target material, (2) material purification and (3) depositing the material $92 \mathrm{a}$ suitable substrate. We describe here in detall our preparation of a ${ }^{148} \mathrm{Gd}$ target. A simllar procedure was used for the remaining radloactive targets. . The results from the various studies performed wh these targets have been pubi1shed elsewhere. $6,7,8$

Table I. Targets for nuclear studles prepared by the LLN Nuclear Propercies Group.

\begin{tabular}{|c|c|c|c|c|}
\hline $\begin{array}{l}\text { Isotoplc } \\
\text { Macerlal } \\
\end{array}$ & $\mathrm{cl} / 2$ & $\begin{array}{l}\text { Material } \\
\text { Production } \\
\text { Technique }\end{array}$ & $\begin{array}{l}\text { Approx. } \\
\text { Thickness }\end{array}$ & $\begin{array}{l}\text { Nuclear } \\
\text { Studies } \\
\text { (reference) } \\
\end{array}$ \\
\hline${ }^{86} \mathrm{Kr}$ & -- & - & $2 \mathrm{~g} / \mathrm{cm}^{2}$ & 2 \\
\hline${ }^{136} \mathrm{xe}$ & - & -- & $2 \mathrm{~g} / \mathrm{cm}^{2}$ & 3 \\
\hline${ }^{148} \mathrm{Gd}$ & $75 y$ & $\begin{array}{l}\mathrm{Ta}+\mathrm{P} \\
\text { spallation }\end{array}$ & $25 \mu \mathrm{g} / \mathrm{cm}^{2}$ & 10 \\
\hline${ }^{151} \mathrm{Sm}$ & $90 y$ & $150_{S D}+n$ & $35 \mu g / \mathrm{cm}^{2}$ & 7 \\
\hline${ }^{152} \mathrm{Eu}$ & $13 y$ & $151_{E u}+n$ & $30 \mu \mathrm{g} / \mathrm{cm}^{2} \mathrm{~m}^{3}$ & 6 \\
\hline${ }^{154} \mathrm{Eu}$ & $8.6 y$ & ${ }^{153} E \mathbf{u}+\mathbf{n}$ & $15 \mu g / \mathrm{cm}^{2}$ & 6 \\
\hline $176_{\mathrm{Lu}}$ & - & - & $22 \mathrm{mg} / \mathrm{cm}^{2}$ & 5 \\
\hline $249_{\mathrm{BK}}$ & $311 d$ & $247 \mathrm{Bk}+2 \mathrm{n}$ & $30 \mu \mathrm{g} / \mathrm{cm}^{2}$ & 8 \\
\hline
\end{tabular}

Raw matertal for the ${ }^{148} \mathrm{Gd}$ target was produced by spallation reactions in a tantalum wetal target by $\sim 750-\mathrm{MeV}$ protons at the Isotopes Production Facility at LMPF. The detalls of the lrradiation and the chemistries assoclated with separating the hafniun and lanthanide fractlons have been reported previously. 9 
The source material we obtalned had been separated frow the lanthanide fraction and contalned gadolinium dissolved in an acidif solution. An assay of th1s material showed that $1 \mathrm{t}$ contained - $170 \mu \mathrm{g}$ of ${ }^{148} \mathrm{Gd}$ and high levels of europlum, samarlum, and terbium contamination. In addition, a high level of lead contamination was present in $\sim 20 \%$ of the sample because of leakage into a shielded contalner during shipping. We used standard 1on-exchange chemistries to remove the lead and rare-earth contaminants and obtalned a clean gadolinium fraction that contained - 132 ug of ${ }^{148} \mathrm{Gd}$.

We prepared samples for the 1sotope separator from the clean gadolinium fraction by electrodeposition. The pure gadolinim fraction was evaporated to dryness, converted to the nitrate, and dissolved $1 \mathrm{n}-200 \mathrm{~mL}$ of $0.1 \mathrm{~N} \mathrm{HNO}$. A 20- $\mathrm{LL}$ allquot was taken from this solution and added to about 1 mL of 1sopropyl alcohol in a small-volume (2 ml) quartz electrodeposition cell. A small platinum disk was sealed to the base of the cell and served as the anode. The cathode, which acted as the collector electrode, was a small strip of tungsten (10 mn $\times 2 \mathrm{~mm} \times 0.03 \mathrm{mr}$ ); 1 t was 1mmersed to a depth of $\sim 3 \mathrm{~mm}$ in the nonaqueous plating solution. We began the deposition by using an applied voltage of $-200 \mathrm{~V}$ and typicaly observed inftial cell currents in the range 0.2 to $0.4 \mathrm{~mA}$. He concluded the plating procedure when the current dropped below $0.1 \mathrm{~ms}$ with an applied voltage of $400 \mathrm{~V}$. The time to complete the deposition was $\sim 1 \mathrm{~h}$. During plating, we adjusted the voltage to maintain cell current in the range 0.2 to $0.5 \mathrm{~mA}$, but did not allow it to exceed 400 $v$. The deposit on the cathode was not chemically identified; it had a white powdery appearance and may have been a hydrated oxide of gadolinlum. Eight tungsten strips cgated with gadolinium were prepared in this way, and the total amount of ${ }^{148} \mathrm{Gd}$ plated was $99 \mu \mathrm{\mu g}$.

We prepared thin targets by collecting a ${ }^{148} \mathrm{Gd}$ beam from the Nuclear Chemistry Isotope Separator ${ }^{4}$ on thin $\left(\sim 50-\mu g / \mathrm{cm}^{2}\right)$ carbon fofts. The gadolinfummcoated tungsten folls each contalned 10 to $15 \mathrm{\mu g}$ of $148 \mathrm{Gd}$. We placed the findividual tungsten folls in the 1sotope separator ton source and collected ${ }^{148} \mathrm{Gd}$ on the carbon foll unt1l the beam became depieted. Approx-imately two coated tungsten folls were required to deposit a 1 ug of $148 \mathrm{Gd}$ on a single carbon foll. We prepared four targets in this manner. We collected the ${ }^{248}$ Gd over an area of about 3 ram $\times 1.5$ m to get target thicknesses raging between about 20 and $30 \mu \mathrm{g} / \mathrm{cm}^{2}$. We estimate that the total amount of ${ }^{4 d}$ finally recovered as usable targets was about 3 to 4 ug or $2.1 \%$ of the original material.

We used the ${ }^{148} \mathrm{Gd}$ targets for a number of charged-particle reaction experfments for nuclear stfucture studfes. 10 For one of the targets, a sample criton spectrum frr, the ${ }^{148} \mathrm{Gd}(\mathrm{p}, \mathrm{t}){ }^{146} \mathrm{Gd}$ reaction is shown in $\mathrm{Fig}$. I which is a couputer reconstruction of the original data on a linear energy scale and combines the results of ilve separate experiments. Each experiment revealed only a portion ( $\sim 20 \%$ ) of the total spectrum. The spectrum is of excellent quality and, in particular, is free from contaminating peaks caused by other rare-earth materials. 


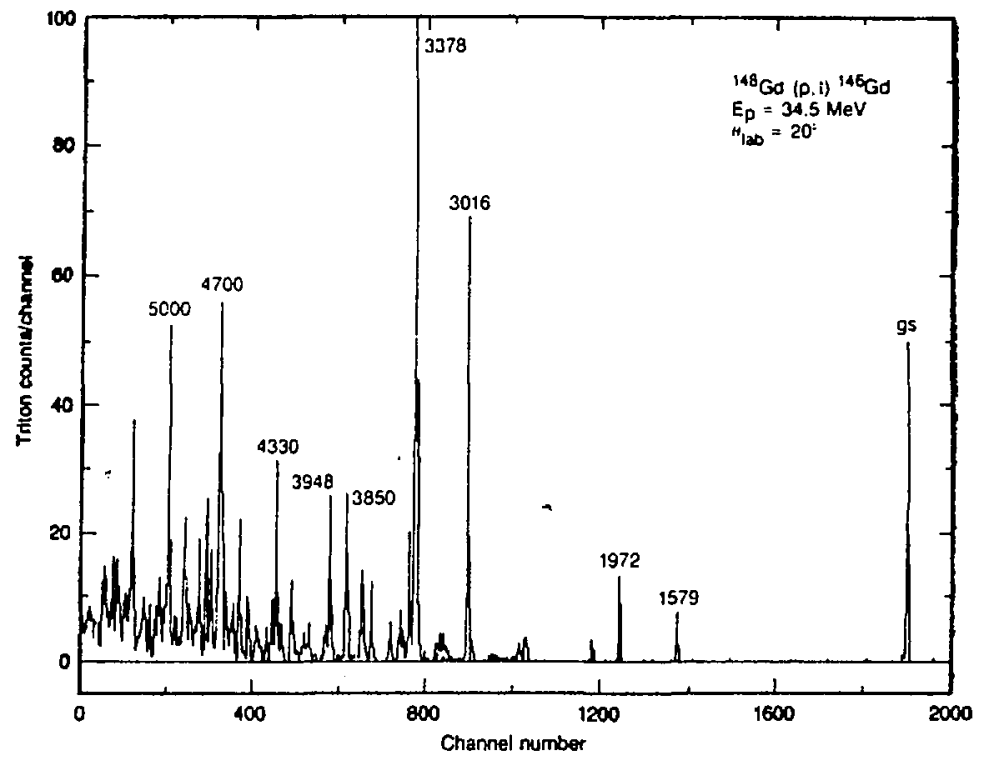

F1g. 1

Table II summarizes the losses we experlenced at each step of the target preparation procedure. As the table shows, the most inefficlent aspect of out technique is the 1sotope separation step. Normally, we expect 30\% recovery with 1sotope separation of gadolinium, but this level was obviously not obtalned in this particular case. With other rare-earth materials, such as europlum and samarium, the expected isotope separation recovery is $>50 \%$ and can reach levels as high as 707. Therefore, allowing for siaflar chemistry losses, expect that in those selected cases where 1sotope separation recoveries are 50\%, the amount of initial material required to make a reasonable number of usuable targets can be as low as $\sim 100 \mathrm{\mu g}$. The amount of Intial materlal required can also be reduced somewhat by paying more attention to Increasing the efficlencies of the wet-cheristry yields.

Proposed future work in our group wil continue to Involve the need for special targets. In particular, we are inyestigating techniques to prepare radioactive targets of $150_{\mathrm{Eu}}(30 \mathrm{y})$ and $227_{\mathrm{Ac}}(22 \mathrm{y})$ for charged-particle spectroscopy work. Each of these targets present special problems which are outside our range of experience and offer considerable technical challenge. Beyond that, we have begun a program to measure light-ion charged-particle cross sections by sctivation and in-beam techniques. Activation studies require the use of many separate target folls. Moreover, each foll must be homogeneous and each must have a thlckness known accurately to a few percent. 
Table II. Yleld sumary for ${ }^{148}$ Gd target preparation.

\begin{tabular}{|c|c|c|c|}
\hline & $\begin{array}{l}\text { Inttial } \\
\text { cleanup } b\end{array}$ & $\begin{array}{l}\text { Electro- } \\
\text { deposition }\end{array}$ & $\begin{array}{l}\text { Ieotope } \\
\text { separacione }\end{array}$ \\
\hline
\end{tabular}

\begin{tabular}{lcccc} 
Mass $(\mu \mathrm{B})$ & 170 & 132 & 99 & 4 \\
Relative yleld $(X)$ & - & 78 & 75 & 4 \\
Cumulative yleld $(z)$ & - & 78 & 58 & 2 \\
\hline
\end{tabular}

${ }^{a}$ The Initial amount of ${ }^{148} \mathrm{Gd}$ was deterained oy alpha-counting a small allquot from the new sample.

${ }^{b}$ The chemical yields were determined by gamma-counting techniques. The sample contalned a number of radloactive 1sotopes of gadoliniun prior to Isotope separation.

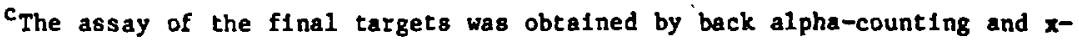
ray fluorescence techniques.

We are experimenting with two schemes to prepare targets for cross-section measurements. The first, is forming a self-supporting "ceramic" target which can be prepared from a metal oxide. This procedure has been used by Quinby, II who prepared self-supporting oxide targets with thicknesses in the range 150$2500 \mathrm{\mu g} / \mathrm{cm}^{2}$ from several materlals. An alternate technique Involves producing thin Kapton ${ }^{12}$ plastic sheets (1-2 mil) which contaln accurately known anounts of any material. The only requirement for the target materlal is that it is in the form of a powder and that the natural particle size $18 \mathrm{mall}$ enough 80 that it can be homogeneously mixed (costed) with the liquid plastic base before spreading and curling. Both techniques show considerable promise for making cheap, high quality targets. for 11 ght-1on studies when low-Z elesent contanination can be tolerated.

\section{Acknowledgments}

This work was performed under the auspices of the U.S. Department of Energy by Lawrence Livermore National Laboratory. under contract No. W-7405-Eng-4E.

I an grateful to Mr. David sisson for his work with the electrodeposition procedures and to Mr. Thomas Masaey for conducting the final purification chemistries.

\section{References}

1. C. M. Jensen, W. M. Buckley, R. G. Lanier, G. L. Struble, S. G. Prussin, and D. H. White, Nuclear Instrum. and Methods 135, 21 (1976).

2. C. M. Jensen, R. G. Lanier, G. L. Struble, L. G. Mann, and S. G. Prussin, Phys. Rev. C 15, 1972 (1977).

3. S. G. Prussin, R. G. Lanier, G. L. Struble, L. G. Mann, and S. M. Schoenung, Phys. Rev, C 16,1001 (1977). 
4. R. J. Dupzyk, C. M. Henderson, H. M. Buckley, G. L. Struble, R. G. Lanier, and L. G. Mann, Nuclear Instrus, and Methode 153, 53 (1978).

5. Jean Kern, University of Fribourg, Pribourg, Switzerland, private comonalcation (1985).

6. See H. E. Martz, R. G. Lanter, G. L. Struble, L. G. Mann, R. K. Sheline, and $W$. Stbffl, Nucl. Phys. A439, 299 (1985) and references thereln.

7. D. Heller, R. T. Kouzes, R. A. Naumann, G. L. Struble, R. G. Lanier, and L. G. Mann, Bull, An. Phys. Soc. 23, 91 (1978).

8. R. A. Dewberry, R. T. Kouzes, R. A. Naumann, R. G. Lanier, H. Börner and R. H. Hoff, Nucl. Phys. A399, 1 (1983).

9. X. E. Thonas, Radiochiolica Acta 34, 135 (1983).

10. A preliminary target of ${ }^{148} \mathrm{Cd}$ was prepared earlier with a sowewhat less rigorous technique. Experimental studies with this target have been published in E. R. Flynn, J. van der Plicht, J. B. Hilhelmy, L. G. Mann, G. L. Struble, and R. G. Lanter, Phys. Rev. C 28, 97 (1983).

11. "Fabrication of Self-Supporting Oxide Targets by Cationic Adsorption in Cellulosic Membranes and Thermal Decomposition," Thomas C. Quinby in Proceeding of Workshop 1983 of the Internatlonal Nuclear Target Development Soclety, Argonne National Laboratory, Argonne, IL, Sept. 7-9, 1983. ANY/PHY-84-2.

12. Trademark E. I. Du Pont de Nemours \& Co. (Inc.) W1lmington, DL 19898. 


\section{DISCLAIMER}

This report was prepared as an account of work sponsored by an agency of the United States Government. Neither the United States Government nor any agency thereof, nor any of their employees, makes any warranty, express or implied, or assumes any legal liability or Iesponsibility for the accuracy, completeness, or usefulness of any information, apparatus, product, or process disclosed, or represents that its use would not infringe privately owned rights. Reference herein to any specific commercial product, process, or service by trade name, trademark, manufacturer, or otherwise does not necessarily constitute or imply its endorsement, recommendation, or favoring by the United States Government or any agency thereof. The views and opinions of authors expressed herein do not necessarily state or reflect those of the United States Government or any agency thereof. 